\title{
The Effect of Effectiveness and Trust on the Use of Village Financial Systems on Village Government Performance
}

\author{
Wildoms Sahusilawane ${ }^{1^{*}}$ \\ ${ }^{1}$ Faculty of Economics, Universitas Terbuka, Indonesia. \\ * Corresponding author: \\ Email: wildoms.s@gmail.com
}

\begin{abstract}
.
This study aims to determine the effect of effectiveness and trust in using the village financial system on village governments' performance in Maluku Province. This study's population is the village government apparatus consisting of the Village Head or Country, Village Secretary, village financial system users, amounting to 63 respondents; the sampling method used in this study is non-probability, namely purposive sampling. Primary data in this study include respondents' answers through questionnaires. The collected questionnaires using multiple correlations and regressions analysis, including descriptive statistics, reliability tests, validity tests, and classical assumptions, including multicollinearity tests and hypothesis testing and discussion. The $\mathrm{F}$ test analysis results show that the effectiveness and trust variables together have a positive and significant effect on the performance of the village government. Based on empirical evidence with t-test or partial with multiple regression models, there is a positive and significant influence between the variables of effectiveness with the performance of the village government and confidence in the village government's performance.
\end{abstract}

\section{Keywords: effectiveness, Trust, Performance.}

\section{INTRODUCTION}

The progress and development of information systems in the current digital era is happening so rapidly; this has influenced the system management of a company and has also had a strong influence on the development of existing accounting information systems in business organizations. The actions that have occurred show that information system technology is no longer a demand for companies or organizations but has become necessary to demonstrate the work of the company or organizational entity to achieve organizational efficiency and effectiveness.

The development of information systems in public sector accounting shows significant results, one of which is applying information systems to the village government. This information system is used to manage and report the use of village funds that have been used and utilized transparently and are based on the principles of good public management to avoid budget misuse and corruption. Based on statutory regulation number 6 of 2014, which ensures that the village government can be more independent in managing the government and its various natural resources, including managing finances and assets belonging to the village. Village government administrators are a sub-system of government administration so that the village can regulate and control the community's interests. The success of government administration can be seen from village development both physically and non- 
physically. However, the success of an information system also depends on the ease of the system and the use of the system by system users because information system technology is carried out in a company to assist individuals in completing their tasks. Lucas and Spitler in research by Amalia (2010), also argue that information technology can be used effectively so that it can contribute to individual performance. Therefore, individuals in the organization must be able to use this information technology properly. One of the essential things that need to be considered in the company is that the application of information technology needs to be implemented by the provisions to bring positive things and improve individual and organizational performance as a whole.

To realize and support government governance in managing village funds, every village that has received village funds is required to report the use of village funds by using the Village Financial System application. In 2015 this system was named Regional Management Information System as a standard in APBDes reporting. The village financial system application has not been fully used and utilized optimally by employees or system users. Its use for processing accounting data and other activities may not always bring convenience to employees.

Ease of use in the village financial system can be seen from the features in the village financial application that are made simple which later in use and operation can simplify and help village officials, especially users of the village financial information system itself so that the performance of the village government is getting better and more effective and efficient. Information technology can impact employees in every type of use of information systems so that information technology can be used effectively to contribute to the achievement of employee performance. Research conducted by Antasari (2015) shows that the effectiveness of the accounting information system has a positive and significant effect on individual performance. If the point of the accounting information system is higher, the individual's performance will also be higher. Jumaili (2005) also disclosed the effectiveness of using and applying information systems within the company that shows the ease of users in identifying, accessing, and interpreting the data.

The implementation of this village financial information system has been utilized in every village, totalling 70,094 villages from 74,958 villages spread over 405 districts/cities throughout Indonesia. Implementing this financial system in Maluku Province is as many as 536 villages from 1,198 villages spread over 11 districts/cities in Maluku province. Based on the description above, in this study, the authors are interested in further analyzing the effect of the effectiveness of use and trust in using the village financial system on the performance of village government in Maluku province. The purpose of this study is (1) to determine whether the effect of the effectiveness of the use of the Village Financial system affects the performance of the Village Government. (2) to determine the effect of trust on the Village Financial System on the performance of the village government. 


\section{METHODS}

In this research, the sample is a village apparatus, namely the Village Head, Village Secretary, staff or Siskeudes operators totalling 63 people. The method used was purposive sampling. The data source in this study is primary data. Primary data is data that is obtained directly from the source, namely the respondents in this study. The primary data obtained consisted of respondents' answers in questionnaires that were distributed directly. The data testing technique used is correlation and regression analysis tools with the help of the SPSS program. The analysis results are descriptive statistics, data quality testing in the form of validity and reliability tests, classical assumption testing, regression analysis and hypotheses and discussion of research results.

\section{RESULT AND DISCUSSION}

Primary data in this study were collected by sending and distributing 70 questionnaires to respondents who served as Village/State Heads, Secretaries and staff or operators using Village Financial System, which were spread across four regions, namely West Seram District, Ambon City, Regency Central Maluku, and Southeast Maluku Regency. The number of questionnaires returned was 66 copies, and the data that could be processed was 63 copies. Researchers classified respondents according to gender, age, years of service, level of education and the length of time using the Siskeudes in their work. The general description of the respondent's profile is shown in Table 1.

\begin{tabular}{|c|c|c|}
\hline \multicolumn{3}{|c|}{ Profile of Respondents } \\
\hline Information & Tota1 & Percentage (\%) \\
\hline $\begin{array}{l}\text { Gender: } \\
\text { a. Male } \\
\text { b. Female }\end{array}$ & $\begin{array}{l}41 \\
22\end{array}$ & $\begin{array}{l}65 \% \\
35 \%\end{array}$ \\
\hline $\begin{array}{l}\text { Age: } \\
\text { a. } 17 \text { to } 26 \text { years } \\
\text { b. } 27 \text { to } 36 \text { years } \\
\text { c. } 37 \text { to } 46 \text { years } \\
\text { d. }>46 \text { years }\end{array}$ & $\begin{array}{c}1 \\
25 \\
26 \\
11\end{array}$ & \begin{tabular}{l|}
$2 \%$ \\
$40 \%$ \\
$41 \%$ \\
$17 \%$ \\
\end{tabular} \\
\hline $\begin{array}{l}\text { Education: } \\
\text { a. High schoo1 } \\
\text { b. Diploma } \\
\text { c. Undergraduate (S1) } \\
\text { d. Masters level (S2) }\end{array}$ & $\begin{array}{c}27 \\
10 \\
25 \\
1\end{array}$ & $\begin{array}{c}43 \% \\
16 \% \\
40 \% \\
2 \%\end{array}$ \\
\hline $\begin{array}{l}\text { Working period: } \\
\text { a. }<1 \text { year } \\
\text { b. } 1 \text { to } 3 \text { years } \\
\text { c. } 3 \text { to } 5 \text { years } \\
\text { d. }>5 \text { years }\end{array}$ & $\begin{array}{c}9 \\
32 \\
9 \\
13\end{array}$ & $\begin{array}{l}14 \% \\
51 \% \\
14 \% \\
21 \% \\
\end{array}$ \\
\hline $\begin{array}{l}\text { O1d time using systems: } \\
\text { a. }<1 \text { year } \\
\text { b. } 1 \text { to } 3 \text { years } \\
\text { c. }>5 \text { years }\end{array}$ & $\begin{array}{c}9 \\
42 \\
12\end{array}$ & $\begin{array}{l}14 \% \\
67 \% \\
19 \%\end{array}$ \\
\hline
\end{tabular}

Table 1 shows that of the 63 respondents, 41 were male or $65 \%$, while the number of female respondents was 22 people or $35 \%$. Furthermore, based on education levels, namely Senior High School as many as 27 people or $43 \%$, Diploma as many as ten people or $16 \%$, Undergraduate (S1) as many as 25 people or $40 \%$, and Masters level (S2) as many as one people or $2 \%$. Furthermore, the average number of respondents who use the village financial system based on the length of time is 1 to 3 years. 
Testing the reliability of the research instrument for each variable shows that the results of the research instrument used are reliable because the value Cronbach Alpha is more significant than 0.60 (Ghozali, 2006). The reliability of each variable can be seen in the following:

Table 2

Reliability Test Results

\begin{tabular}{|l|l|c|l|}
\hline No & \multicolumn{1}{|c|}{ Variable } & $\begin{array}{c}\text { Value Cronbach } \\
\text { Alpha }\end{array}$ & Information \\
\hline 1 & Effectiveness & 0.902 & Reliable \\
\hline 2 & Trust & 0.911 & Reliable \\
\hline 3 & Village Government Performance & 0.913 & Reliable \\
\hline
\end{tabular}

Table from table 2 above shows the value Cronbach Alpha of each variable used in this study, namely the effectiveness variable, the trust variable and the village government performance variable indicating a value $>0.60$, which means that the instruments in this study are reliable or reliable. The data validity test was carried out with Pearson. Correlation to test the correlation of each question item score against the total variable score. The validity test results show that each question item leads to a significant impact (at the 0.05 level). So it can be seen that each of the question indicators used in the research instrument is valid. The result of multicollinearity presented in table 3 represents the value of Tolerance and Variance Inflation Factor (VIF). The test result shows that the value of Tolerance is no less than 0,10 , while that of VIF is no more than 10 , which proposes that there is no sign of multicollinearity among the variables (Ghozali, 2006). The result of multicollinearity test can be seen in the following table:

Table 3

Multicollinearity Test Results

\begin{tabular}{|l|c|c|c|}
\hline \multicolumn{1}{|c|}{ Variable } & Tolerance & VIF & Information \\
\hline Effectiveness & 0.524 & 1.908 & No multicollinearity \\
\hline Trust & 0.524 & 1.908 & No multicollinearity \\
\hline
\end{tabular}

The coefficient of determination (R2), in essence, measures how far the model's ability to explain the variation in the dependent variable. The coefficient of determination is between zero and one. The small value of R2 means that the power of the independent variables to explain the variation in the dependent variable is very limited.

Table 4 shows the results of the coefficient of determination:

Table 4

Coefficient of Determination

Model Summary

\begin{tabular}{|c|c|c|c|c|}
\hline Model & $\mathrm{R}$ & $\mathrm{R}$ Square & $\begin{array}{c}\text { Adjusted } \mathrm{R} \\
\text { Square }\end{array}$ & $\begin{array}{c}\text { Std. Error of } \\
\text { the Estimate }\end{array}$ \\
\hline 1 & $.849^{\mathrm{A}}$ & .720 & .771 & 1.441 \\
\hline
\end{tabular}
a. Predictors: (Constant), K, E

b. Dependent Variable: KP

Table 4 above shows that the adjusted R2 value is 0.711 or $71.1 \%$, which means that the independent variable can explain the dependent variable by $71.1 \%$. In comparison, the rest $(100 \%-71.1 \%=28,9 \%)$ were described by other factors not included in this analysis. The $\mathrm{F}$ test is used to see whether there is a joint (simultaneous) influence of the independent variable on the dependent variable. Table 5 below are the results of the simultaneous significance test (Test Statistic F). 
Table 5

F-Test Results

ANOVA ${ }^{b}$

\begin{tabular}{|c|c|c|c|c|c|c|}
\hline & Model & Sum of Squares & $\mathrm{df}$ & Mean Square & $\mathrm{F}$ & Sig. \\
\hline \multirow[t]{3}{*}{1} & Regression & 320,921 & 2 & 160,460 & 77,247 & $.000^{\mathrm{a}}$ \\
\hline & Residual & 124,635 & 60 & 2,077 & & \\
\hline & Total & 445,556 & 62 & & & \\
\hline
\end{tabular}

The table above shows the calculated $\mathrm{F}$ value of 77.247 at the significance level of 0.000 , which is less than 0.05 . It can be stated that there is a significant influence between the effectiveness variable and the trust variable jointly affecting the performance of the village government. The results of the t-test are used to determine the effect of one explanatory variable individually in explaining the variation in the dependent variable. The results of the partial test (t-test) can be seen in the following table:

Table 6

Statistical Test Results $t$

\begin{tabular}{|c|c|c|c|c|c|c|}
\hline \multirow{2}{*}{\multicolumn{2}{|c|}{ Model }} & \multicolumn{2}{|c|}{ Unstandardized Coefficients } & \multirow{2}{*}{$\begin{array}{c}\text { Standardized } \\
\text { Coefficients } \\
\text { Beta } \\
\end{array}$} & \multirow[b]{2}{*}{$\mathrm{t}$} & \multirow[b]{2}{*}{ Sig. } \\
\hline & & $\mathrm{B}$ & Std. Error & & & \\
\hline \multirow[t]{3}{*}{1} & (Constant) & 1.972 & 2.032 & & .971 & .336 \\
\hline & $\mathrm{E}$ & .232 & .087 & .252 & 2,673 & .010 \\
\hline & $\mathrm{K}$ & .656 & .094 & .655 & $.6,944$ & .000 \\
\hline
\end{tabular}

The results of the t-test for variable of effectiveness in the use of the village financial system show a significance level of 0.010 . This value is less than 0.05 , so it can be concluded that Ho is accepted, which means that the effectiveness of using Siskeudes partially has a significant effect on the performance of the village government.

The results of the $t$-test for variable trust in the village financial system show a significance level of 0.000 which is smaller than 0.05 , so it can be concluded that $\mathrm{H}_{0}$ is rejected, which means that the variable trust in Siskeudes partially has a significant effect on the performance of the village government. Based on the $t$ statistical test results above, the statistical test of the effectiveness variable shows a significance value of 0.010 , which is greater than the alpha value of 0.05 . For this reason, it can conclude that the effectiveness variable influences the performance of the village government, in line with research conducted by Ratna Sari (2009), which shows that the effectiveness of the use of information system technology has a significant effect on individual performance. In addition, this research is also in line with Ariyanto (2008) research, which shows the effectiveness of information systems technology is positive effect on individual performance. Thus this study indicates that the use of the village financial system is very effective and easy to improve the performance of village government officials.

Based on the results of statistical tests, it shows that the trust variable has a significance value of 0.000 and has a positive effect on the performance of the village government. This is in line with the research by Jumaili (2005) and Ratna Sari (2009), which shows that trust has an effect on individual performance. Based on the study results, trust has a positive and significant effect on the performance of the village government. This means that the village financial system users assume that their confidence in using the village financial system will be higher with this 
information system. The performance of each individual in the village government is getting higher.

\section{CONCLUSION}

Based on the data analysis that has carried out, the researcher can draw some conclusions, as follows (1) effectiveness of the use of the village financial system has a positive effect on the performance of the village government. (2) Trust in the village financial system has a positive and significant effect on the village government's performance. (3) based on empirical evidence with the F test or simultaneously, known that there is a positive and significant influence of effectiveness and trust in the performance of the village government.

Based on these conclusions, some suggestions are forward as follows: further research can add other variables because it is not limited to the tested variables but technical factors to support the implementation of the use of Siskeudes. It is also necessary to conduct research with a larger sample and not be limited to the village government but extended to all village governments in the city and district. Moreover, it is necessary to develop an instrument adjusted to the conditions and environment of the object under study.

\section{REFERENCES}

[1] Amalia, S. (2010). Persepsi Pegawai Pajak Terhadap Pemanfaatan Teknologi Informasi Pada Kinerja Individual (Studi Kasus pada KPP Pratama Tegal). Universitas Diponegoro.

[2] Antasari, K. C., \& S, P. D. Y. (2015). Pengaruh Efektivitas Sistem Informasi Akuntansi Dan Penggunaan Teknologi Informasi Pada Kinerja Individual Dengan Kepuasan Kerja Sebagai Variabel Pemoderasi. E-Jurnal Akuntansi, 10(2), 354-369.

[3] Ariyanto, D. (2008). Pengaruh Efektivitas Penggunaan dan Kepercayaan Teknologi Sistem Informasi Terhadap Kinerja Individual. Jurnal Ilmiah Akuntansi dan Bisnis, 3(1).

[4] Ghozali, Imam. 2006. Aplikasi Analisis Multivariate Dengan Program SPSS. Semarang, Universitas Diponegoro.

[5] Jumaili, S. (2005). Kepercayaan Terhadap Teknologi Sistem Informasi Baru Dalam Evaluasi Kinerja Individual. Simposium Nasional Akuntansi VIII Solo, (September), 1516.

[6] Ratna Sari, M. (2009). Pengaruh Efektivitas Penggunaan dan Kepercayaan Terhadap Teknologi Sistem Informasi Aakuntansi Terhadap Kinerja Individual Pada Pasar Swalayan di Kota Denpasar. Jurnal Ilmiah Akuntansi Dan Bisnis, 4(1).

[7] Republik Indonesia. 2014. Undang-undang No 6 Tahun 2014 Tentang Desa

[9] http://www.bpkp.go.id/public/upload/unit/sakd/files/Juklakbimkonkeudesa.pdf, diakses tanggal 7 April 2020. 